\title{
Potential of Metropolitan Greenspaces on Global Warming Abatement in Lagos, Southwestern Nigeria
}

\author{
${ }^{* 1}$ BADA, BS; ${ }^{2}$ MUSARI, OT; ${ }^{1}$ TOWOLAWI, AT \\ ${ }^{* 1}$ Department of Environmental Management and Toxicology, Federal University of Agriculture, Abeokuta, Ogun State, Nigeria. \\ ${ }^{2}$ Lagos State Ministry of Environment, Alausa, Ikeja, Lagos State, Nigeria. \\ *Corresponding author Email: badabs@funaab.edu.ng Tel: +234(0)8037250964; other Emails: successfuloladunni12@ gmail.com; \\ taofiktowolawi@yahoo.com
}

\begin{abstract}
Greenspace campaign regulates urban air quality and global warming effects. Four areas with trees planting (TP: Ojota-Ketu, Anthony, Costain and Airport-Agege) and non-trees planting (NP: Mile 12, Jibowu, Ojuelegba and Iyana-ipaja) were selected considering traffic volumes. Gaseous pollutants: $\mathrm{CO}, \mathrm{CO}_{2}, \mathrm{NO}_{\mathrm{x}}, \mathrm{SO}_{2}, \mathrm{VOC}$; SPM and noise levels; meteorological conditions: $\mathrm{O}_{2}$ and Temperature in the selected areas were assessed to be TP and $\mathrm{NP}$ were $\mathrm{CO}: 3.76 \pm 1.23$ and $4.70 \pm 1.59 \mu \mathrm{g} / \mathrm{m}^{3}, \mathrm{CO}_{2}: 8.39 \pm 1.50$ and $14.68 \pm 2.62 \mu \mathrm{g} / \mathrm{m}^{3}, \mathrm{NO}_{2}: 1.94 \pm 0.84$ and $2.57 \pm 1.11 \mu \mathrm{g} / \mathrm{m}^{3}, \mathrm{SO}_{2}: 0.32 \pm 0.54$ and $0.46 \pm 0.77 \mu \mathrm{g} / \mathrm{m}^{3}$, VOC: $2.08 \pm 0.65$ and $2.60 \pm 1.66 \mu \mathrm{g} / \mathrm{m}^{3}, \mathrm{SPM}: 101.5 \pm$ 26.19 and $189.34 \pm 48.99 \mu \mathrm{g} / \mathrm{m}^{3}$, Temp.: $41.25 \pm 6.92$ and $45.38 \pm 7.26^{\circ} \mathrm{C}, \mathrm{O}_{2}: 28.25 \pm 2.74$ and $21.73 \pm 2.09 \%$, and Noise: $93.75 \pm 37.21$ and $112.50 \pm 44.65 \mathrm{~dB}$. Gaseous pollution levels were below the standards at the TP. Levels of SPM were generally lower but Temperature was higher than the limit. Greenspace significance to improve urban air quality and abate global warming was observed.
\end{abstract}

\section{DOI:https://dx.doi.org/10.4314/jasem.v23i1.14}

Copyright: Copyright $\odot 2019$ Bada et al. This is an open access article distributed under the Creative Commons Attribution License (CCL), which permits unrestricted use, distribution, and reproduction in any medium, provided the original work is properly cited.

Dates: Received: 11 December 2018; Revised: 19 January 2019; Accepted 22 January 2019

Keywords: Vehicular emission, meteorological conditions, Global warming abatement, Lagos.

Continuous growth in human population, vehicular traffic and industries had increased urban levels of gaseous and particulate pollutants over the years. One of the dominant sources of air quality deterioration is road traffic-induced (Kumar et al., 2013). The effects have a direct relationship with deterioration in overall human health and account for half of the outdoorinduced problems. Another undesired and unpleasant factor that creates nuisance in the urban center is noise which affects the quality of life through ear impairment. Noise negatively has intervention on communication, productivity and social behaviour of man (Haq et al., 2014). Various approaches to reduce urban and environmental pollution have considered urban tree planting areas (greenspaces) and its orientation for bio-aesthetic values, thereby making cities habitable, conducive, and contributing to human health and well-being. Vegetation and land cover removal have given way to an artificial urban landscape with concrete and tar (Olayemi and Oluwafemi, 2013). Urban heat island effect is mitigated with increase in urban greenspaces with relative contribution of evapotranspiration overall cooling effect, this in turn increases oxygen levels and lowers the average temperature of the environment below $30{ }^{\circ} \mathrm{C}$ ( $\left.\mathrm{DoH}, 2008\right)$. The study assessed mitigating effects of greenspaces on the air quality and potential global warming in selected areas within Lagos State metropolis.

\section{MATERIALS AND METHODS}

Study area: Lagos is the most urbanized state in Nigeria with 17, 500 hectares of built up area (Oduwaye, 2006), which makes its natural land cover area witness a dramatic shift as a result of massive urban development. Lagos State is located in the southwestern coast of Nigeria between latitudes $6^{\circ} 22^{\prime} \mathrm{N}$ and $6^{\circ} 52^{\prime} \mathrm{N}$ and longitudes $2^{\circ} 42^{\prime} \mathrm{E}$ and $3^{\circ} 42^{\prime} \mathrm{E}$. The area is characterized by a wet equatorial climate with mean annual rainfall above $1800 \mathrm{~mm}$. An important part of the land resource in the state comprises saltwater and freshwater wetlands. The former covers the mangrove swamps along the coast of the study area. The greenspace areas in Lagos metropolis monitored were Ojota-Ketu;- 39, 161.30 $\mathrm{m}^{2}$, Anthony;- 15, $679.34 \mathrm{~m}^{2}$, Costain:- 11, $750.25 \mathrm{~m}^{2}$ and Airport-Agege; 42, $900.34 \mathrm{~m}^{2}$ (Olaleye, 2013) while the non-greenspaces were Mile 12, Jibowu, Ojuelegba and Iyana-ipaja.

Sampling sites and parameters: The eight selected locations for the study were four greenspaces and four non-greenspaces (Figure 1). The areas were 
chosen for population density and traffic volume. Gaseous pollutants, meteorological conditions, particulate matter and noise were assessed. The parameters were monitored with battery-operated hand-held equipment: Land-duo (Industracom, North Sydney, Australia) for $\mathrm{CO}, \mathrm{CO}_{2}, \mathrm{NO}_{2}$ and $\mathrm{O}_{2}$, $\mathrm{QRAE}^{+}$meter (Fisher Scientific, Loughborough, UK) for $\mathrm{SO}_{2}, \mathrm{VOC}$ and $\mathrm{T}^{\mathrm{O}} \mathrm{C}$, DustTrak (TSI, Air Met Scientific, UK) for SPM and SD-200 (Air Met Scientific, UK) for noise level. According to Thomasnet (2011), the equipment were placed $2.5 \mathrm{~m}$ above ground level, where man is exposed to the prevailing pollutants and the sampling was carried out for 1 hour before the fluctuated values were recorded. The equipment were gaseous sensor inbuilt, which identified, quantified and digitised the existing gaseous parameters in the sampling locations.

Statistical analyses: The data collected were subjected to descriptive (mean and standard deviation) and inferential statistics (one-way ANOVA and Duncan's Multiple Range Test at $\mathrm{p}<$ $0.05)$.

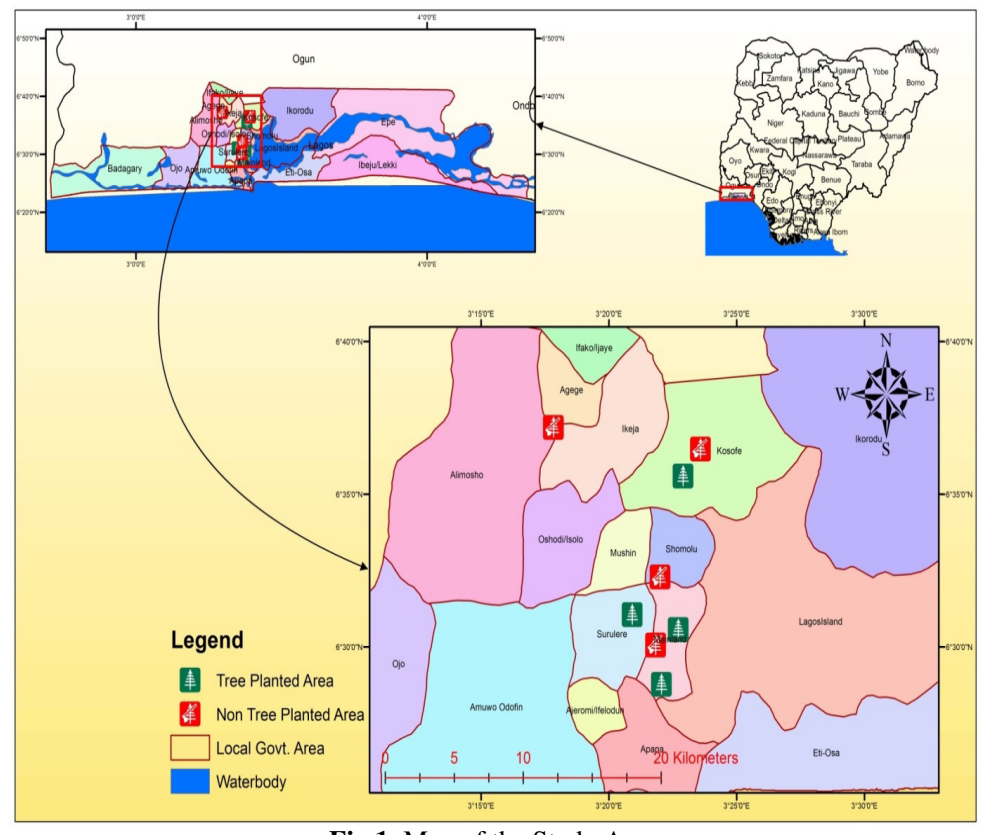

Fig 1: Map of the Study Area,

Trees Planted Areas $=$ greenspaces, Non Tree Planted Area $=$ non- greenspaces

\section{RESULTS AND DISCUSSION}

Levels of the gaseous parameters in greenspaces: From Table 1, levels of CO ranged from $2.10 \pm 0.36$ along Airport-Agege to $3.03 \pm 0.25 \mu \mathrm{g} / \mathrm{m}^{3}$ along Costain. Its concentration was highly significant $(\mathrm{p}<$ 0.05 ) on the environment and the same along both Ojota-Ketu and Airport-Agege roadsides. Levels of $\mathrm{CO}_{2}$ ranged from $5.30 \pm 0.36$ along Airport-Agege to $5.90 \pm 0.36 \mu \mathrm{g} / \mathrm{m}^{3}$ along Costain $(\mathrm{p}>0.05)$. Levels of $\mathrm{NO}_{2}$ ranged from $1.05 \pm 0.18$ along Airport-Agege to $1.52 \pm 0.13 \mu \mathrm{g} / \mathrm{m}^{3}$ along Costain ( $\mathrm{p}>0.05$ ). Levels of $\mathrm{SO}_{2}$ ranged from $0.12 \pm 0.13$ along AirportAgege to $0.35 \pm 0.10 \mu \mathrm{g} / \mathrm{m}^{3}$ along Costain $(\mathrm{p}>0.05)$. Levels of VOC ranged from $1.11 \pm 0.13$ along Airport-Agege to $1.58 \pm 0.31 \mu \mathrm{g} / \mathrm{m}^{3}$ along Ojota-Ketu significantly $(\mathrm{p}<0.05)$. The detected values from the study were compared with the EC (2016) limits for all the sampling locations within $1 \mathrm{hr}$ period. The $\mathrm{CO}$ levels were less than the limit: $40 \mu \mathrm{g} / \mathrm{m}^{3}$. Levels of $\mathrm{CO}_{2}$ did not exceed the limit $\left(10 \mu \mathrm{g} / \mathrm{m}^{3}\right)$. Levels of
$\mathrm{NO}_{2}$ were below the limit $\left(191-200 \mu \mathrm{g} / \mathrm{m}^{3}\right)$. Also, the levels of $\mathrm{SO}_{2}$ were below the limit (198.75 - 350 $\mu \mathrm{g} / \mathrm{m}^{3}$ ) (Table 1). It could be deduced that the levels $\left(\mu \mathrm{g} / \mathrm{m}^{3}\right)$ of gaseous pollutants determined were least along Airport-Agege with the highest greenspace area of 42, $900 \mathrm{~m}^{2}$ while highest along Costain with the lowest greenspace area of $11,750.25 \mathrm{~m}^{2}$. High volume of vehicle moving into and from Apapa and Island as well as industrial emissions from the area (Singh, 2004) might have been responsible for the high levels of pollution in Costain.

Levels of the gaseous parameters in nongreenspaces: From Table 2, levels of CO ranged significantly $(\mathrm{p}<0.05)$ from $2.63 \pm 0.45$ along Jibowu to $3.79 \pm 0.31 \mu \mathrm{g} / \mathrm{m}^{3}$ along Iyana-ipaja. Levels of $\mathrm{CO}_{2}$ ranged with not significant $(\mathrm{p}>0.05)$ different from $9.28 \pm 0.63$ along Jibowu to $10.33 \pm$ $0.63 \mu \mathrm{g} / \mathrm{m}^{3}$ along Iyana-ipaja. Levels of VOC ranged significantly $(\mathrm{p}<0.05)$ from $1.39 \pm 0.16$ along 
Jibowu to $1.98 \pm 0.38 \mu \mathrm{g} / \mathrm{m}^{3}$ along Ojuelegba. However, its levels were not significantly $(\mathrm{p}>0.05)$ different along both Ojuelegba and Iyana-ipaja. Levels of $\mathrm{NO}_{2}$ ranged $(\mathrm{p}>0.05)$ from $1.39 \pm 0.24$ along Jibowu to $2.00 \pm 0.17 \mu \mathrm{g} / \mathrm{m}^{3}$ along Iyana-ipaja. Levels of $\mathrm{SO}_{2}$ ranged $(\mathrm{p}>0.05)$ from $0.50 \pm 0.15$ to $0.34 \pm 0.18 \mu \mathrm{g} / \mathrm{m}^{3}$. Levels of $\mathrm{CO}$ were less than the limit: $40 \mu \mathrm{g} / \mathrm{m}^{3}$ along all the sampling locations for 1 hr period. Levels of $\mathrm{CO}_{2}$ were less than the limit: 10 $\mu \mathrm{g} / \mathrm{m}^{3}$. The levels of $\mathrm{CO}_{2}$ detected at the monitoring hour indicated that its contribution would have been from the vehicle volume because one of the dominant sources of urban pollution is road-traffic-induced. Significant difference in VOC level indicated that deadly ground $\mathrm{O}_{3}$ might also be significantly different in all the areas because VOC has directly correlated with the variation of $\mathrm{O}_{3}$ but negative correlation with
NOx. Levels of $\mathrm{NO}_{\mathrm{X}}$ were below the limit: $191-200$ $\mu \mathrm{g} / \mathrm{m}^{3}$. The low levels of $\mathrm{NO}_{\mathrm{X}}$ recorded might have increased $\mathrm{CH}_{4}$ and $\mathrm{O}_{3}$ to corroborate West et al. (2007) view that NOx reduction increased $\mathrm{CH}_{4}$ and long term ozone $\left(\mathrm{O}_{3}\right)$. Level of $\mathrm{NO}_{\mathrm{X}}$ enhances the magnitude of effects observed with other pollutants, is a good indicator of traffic-related air pollution and an important source of a range of more toxic pollutants that could act in combination to produce adverse health effects. Several studies among occupational groups exposed to traffic fumes have documented adverse effects including lung cancer and lung function changes (Karita et al., 2001). Levels of $\mathrm{SO}_{2}$ were above the threshold (198.75 $350 \mu \mathrm{g} / \mathrm{m}^{3}$ ) in all the sampling locations within $1 \mathrm{hr}$ sampling period (EC, 2016) with possible occurrence acid rain.

Table 1: Results of the air quality parameters at the greenspaces

\begin{tabular}{llllll}
\hline & Ojota-Ketu & Anthony & Costain & Airport-Agege & \\
\hline $\begin{array}{l}\text { Area covered } \\
\text { by trees }\left(\mathrm{m}^{2}\right)\end{array}$ & $39,161.30$ & $15,679.34$ & $11,750.25$ & $42,900.34$ & (Olaleye, 2013) \\
\hline Parameters & & & & Threshold \\
\hline $\mathrm{CO}\left(\mu \mathrm{g} / \mathrm{m}^{3}\right)$ & $2.16 \pm 0.42^{\mathrm{a}}$ & $2.73 \pm 0.2^{\mathrm{ab}}$ & $3.03 \pm 0.25^{\mathrm{b}}$ & $2.10 \pm 0.36^{\mathrm{a}}$ & $40(\mathrm{EC}, 2016)$ \\
$\mathrm{CO}_{2}\left(\mu \mathrm{g} / \mathrm{m}^{3}\right)$ & $5.37 \pm 0.42^{\mathrm{a}}$ & $5.80 \pm 0.36^{\mathrm{a}}$ & $5.90 \pm 0.36^{\mathrm{a}}$ & $5.30 \pm 0.36^{\mathrm{a}}$ & $10(\mathrm{EC}, 2016)$ \\
$\mathrm{NO}_{2}\left(\mu \mathrm{g} / \mathrm{m}^{3}\right)$ & $1.25 \pm 0.40^{\mathrm{a}}$ & $1.37 \pm 0.13^{\mathrm{a}}$ & $1.52 \pm 0.13^{\mathrm{a}}$ & $1.05 \pm 0.18^{\mathrm{a}}$ & $191-200(\mathrm{EC}, 2016)$ \\
$\mathrm{SO}_{2}\left(\mu \mathrm{g} / \mathrm{m}^{3}\right)$ & $0.15 \pm 0.18^{\mathrm{a}}$ & $0.23 \pm 0.13^{\mathrm{a}}$ & $0.35 \pm 0.10^{\mathrm{a}}$ & $0.12 \pm 0.13^{\mathrm{a}}$ & $198.75-350(\mathrm{EC}, 2016)$ \\
$\mathrm{VOC}\left(\mu \mathrm{g} / \mathrm{m}^{3}\right)$ & $1.58 \pm 0.31^{\mathrm{b}}$ & $1.37 \pm 0.13^{\mathrm{ab}}$ & $1.48 \pm 0.08^{\mathrm{b}}$ & $1.11 \pm 0.13^{\mathrm{a}}$ & ---- \\
\hline \multicolumn{6}{c}{ Values with the same superscripts along the row were not significantly $(p>0.05)$ different }
\end{tabular}

Table 2: Results of the air quality parameters at the non-greenspaces

\begin{tabular}{llllll}
\hline Parameters & Mile 12 & Jibowu & Ojuelegba & Iyana-ipaja & Threshold \\
\hline $\mathrm{CO}\left(\mu \mathrm{g} / \mathrm{m}^{3}\right)$ & $3.42 \pm 0.31^{\mathrm{ab}}$ & $2.63 \pm 0.45^{\mathrm{a}}$ & $2.71 \pm 0.52^{\mathrm{a}}$ & $3.79 \pm 0.31^{\mathrm{b}}$ & $40(\mathrm{EC}, 2016)$ \\
$\mathrm{CO}_{2}\left(\mu \mathrm{g} / \mathrm{m}^{3}\right)$ & $10.15 \pm 0.63^{\mathrm{a}}$ & $9.28 \pm 0.63^{\mathrm{a}}$ & $9.39 \pm 0.73^{\mathrm{a}}$ & $10.33 \pm 0.63^{\mathrm{a}}$ & $10(\mathrm{EC}, 2016)$ \\
$\mathrm{NO}_{2}\left(\mu \mathrm{g} / \mathrm{m}^{3}\right)$ & $1.80 \pm 0.17^{\mathrm{a}}$ & $1.39 \pm 0.24^{\mathrm{a}}$ & $1.65 \pm 0.53^{\mathrm{a}}$ & $2.00 \pm 0.17^{\mathrm{a}}$ & $191-200(\mathrm{EC}, 2016)$ \\
$\mathrm{SO}_{2}\left(\mu \mathrm{g} / \mathrm{m}^{3}\right)$ & $0.34 \pm 0.18^{\mathrm{a}}$ & $0.17 \pm 0.18^{\mathrm{a}}$ & $0.22 \pm 0.26^{\mathrm{a}}$ & $0.50 \pm 0.15^{\mathrm{a}}$ & $198.75-350(\mathrm{EC}, 2016)$ \\
$\mathrm{VOC}\left(\mu \mathrm{g} / \mathrm{m}^{3}\right)$ & $1.71 \pm 0.16^{\mathrm{ab}}$ & $1.39 \pm 0.16^{\mathrm{a}}$ & $1.98 \pm 0.38^{\mathrm{b}}$ & $1.85 \pm 0.96^{\mathrm{b}}$ & --- \\
\hline \multicolumn{5}{c}{ Values with the same superscripts along the row were not significantly $(p>0.05)$ different }
\end{tabular}

Meteorological condition in the greenspaces: As shown in Table 3, the atmospheric temperature of the areas ranged with no significant $(\mathrm{p}>0.05)$ difference from $26.33 \pm 2.31$ (Airport-Agege) to $28.66 \pm 1.15$ ${ }^{\circ} \mathrm{C}$ (Costain). The atmospheric temperature did not exceed the limit for urban heat island during the day, $30{ }^{\circ} \mathrm{C}(\mathrm{DoH}, 2008)$. The oxygen levels of the areas ranged significant $(\mathrm{p}<0.05)$ from $17.33 \pm 0.58$ to $20.67 \pm 0.58 \%$; lowest in Costain but highest in Airport-Agege areas. This oxygen level would make where it was highest (Airport-Agege) the most conducive area.

Meteorological condition in the non-greenspace: As shown in Table 4, temperature of the study areas ranged with no significant $(\mathrm{p}>0.05)$ different from $28.97 \pm 2.54$ along Jibowu to $31.53 \pm 1.27{ }^{\circ} \mathrm{C}$ along Iyana-ipaja. Oxygen levels ranged significantly $(\mathrm{p}<$ 0.05 ) from $13.33 \pm 0.44$ to $15.90 \pm 0.44 \%$ in all the areas; highest along Jibowu but lowest along Iyanaipaja. Anthropogenic activities (mostly transportation with vehicular emissions) in Iyana-ipaja were high, and it is where Ikotun and Agege axes traverse Ikeja and Agabado-Ijaye axes with no greenspaces at all. Atmospheric temperature of both Jibowu and Ojuelegba was lower while Mile 12 and Iyana-ipaja values were higher than the urban heat island limit: $30{ }^{\circ} \mathrm{C}$ (DoH, 2008). Rise in temperature levels could influence dispersion of vehicular emissions with resultant poor air quality. Temperature has been traced to be a predominant parameter that affects concentration of $\mathrm{O}_{3}$, which is one of the criteria of pollutants (Kumar et al., 2013). This also complied with the view that SPM had positive correlation with temperature in all the seasons, especially from October to December which is equivalent to harmattan period in Nigeria. Influence of temperature on gaseous pollutants (such as $\mathrm{SO}_{2}$ and $\mathrm{NOx}$ ) could be more predominantly effective in dry season than other seasons due to higher trends and variations. However, the study showed that Jibowu was the most conducive area having highest oxygen level value. 
Table 3: Results of the meteorological conditions at the greenspaces

\begin{tabular}{llllll}
\hline \multicolumn{7}{c}{ Ojota-Ketu } & Anthony & Costain & Airport-Agege \\
\hline $\begin{array}{l}\text { Area covered } \\
\text { by trees }\left(\mathrm{m}^{2}\right)\end{array}$ & $39,161.30$ & $15,679.34$ & $11,750.25$ & $42,900.34$ & (Olaleye, 2013) \\
\hline Parameters & & & & Threshold \\
\hline Temp. $\left({ }^{\circ} \mathrm{C}\right)$ & $27.00 \pm 1.73^{\mathrm{a}}$ & $28.00 \pm 1.73^{\mathrm{a}}$ & $28.66 \pm 1.15^{\mathrm{a}}$ & $26.33 \pm 2.31^{\mathrm{a}}$ & $<30(\mathrm{DoH}, 2008)$ \\
$\mathrm{O}_{2}(\%)$ & $19.00 \pm 1.00^{\mathrm{b}}$ & $18.33 \pm 0.58^{\mathrm{ab}}$ & $17.33 \pm 0.58^{\mathrm{a}}$ & $20.67 \pm 0.58^{\mathrm{c}}$ & ----- \\
\hline \multicolumn{5}{c}{ Values with the same superscripts along the row were not significantly $(p<0.05)$ different. }
\end{tabular}

Table 4: Results of the meteorological conditions at the non-greenspaces

\begin{tabular}{|c|c|c|c|c|c|}
\hline Parameters & Mile 12 & Jibowu & Ojuelegba & Iyana-ipaja & \\
\hline & & & & & Threshold \\
\hline Temp. $\left({ }^{\circ} \mathrm{C}\right)$ & $30.80 \pm 1.90^{\mathrm{a}}$ & $28.97 \pm 2.54^{\mathrm{a}}$ & $29.70 \pm 1.91^{\mathrm{a}}$ & $31.53 \pm 1.27^{\mathrm{a}}$ & $<30(\mathrm{DoH}, 2008)$ \\
\hline $\mathrm{O}_{2}(\%)$ & $14.10 \pm 0.44^{\mathrm{ab}}$ & $15.90 \pm 0.44^{\mathrm{c}}$ & $14.62 \pm 0.77^{b}$ & $13.33 \pm 0.44^{\mathrm{a}}$ & ---- \\
\hline
\end{tabular}

Levels of SPM and noise in greenspaces: Levels of SPM ranged significantly $(\mathrm{p}<0.05)$ from $58.33 \pm$ 4.73 along Airport-Agege to $78.33 \pm 7.23 \mu \mathrm{g} / \mathrm{m}^{3}$ along Costain while noise levels of the areas ranged with no significant $(\mathrm{p}>0.05)$ different from $59.00 \pm$ 10.00 along Airport-Agege to $67.00 \pm 7.21 \%$ along Costain (Table 5). Levels of SPM along the areas were below the limit $\left(150-250 \mu \mathrm{g} / \mathrm{m}^{3}\right)$ set by EC (2016) while noise level along Costain was lower than threshold for human health: $70 \mathrm{~dB}$ (WHO, 2000).

Levels of the SPM and noise in non-greenspace: The levels of SPM ranged significantly $(\mathrm{p}<0.05)$ from $109.08 \pm 8.84$ along Jibowu to $146.48 \pm 13.53 \mu \mathrm{g} / \mathrm{m}^{3}$ along Iyana-ipaja while noise ranged with no significant $(\mathrm{p}>0.05)$ different from $70.80 \pm 12.00$ along Jibowu to $80.40 \pm 8.65 \mathrm{~dB}$ along Iyana-ipaja (Table 6). Levels of SPM were lower than the limit: $150-250 \mu \mathrm{g} / \mathrm{m}^{3}$ (EC, 2016). Lung function growth rate had been reported to change with relocation of children to areas with higher or lower levels than before. Exposure to pollutants such as SPM and $\mathrm{O}_{3}$ (ozone) had been found associated with increases in hospital admissions for cardiovascular and respiratory disease, as well as mortality in many cities in Europe and other continents (Ezzati, 2002).

Comparison of average levels of the assessed parameters in both areas: To compare levels of air quality and climate change possibility around both greenspaces and non-greenspaces, average value of each parameter was computed (Tables 7-9). Levels of average gaseous parameters were lower at the greenspaces than the non-greenspaces (Table 7). The greenspace areas had lower average temperature levels than non-greenspace (Table 8). Levels of the SPM were relatively high (Table 9). Average levels of all the parameters were observed to be higher around the non-greenspaces (Figure 2). From Table 7 , the average levels of all the gaseous parameters were lower than the limits except $\mathrm{CO}_{2}: 14.68 \pm 2.62$ $\mu \mathrm{g} / \mathrm{m}^{3}$ which exceeded the limit: $10.00 \mu \mathrm{g} / \mathrm{m}^{3}$.

Table 5: Results of the SPM and noise at the greenspaces

\begin{tabular}{llllll}
\hline & Ojota-Ketu & Anthony & Costain & Airport-Agege & \\
\hline $\begin{array}{l}\text { Area covered } \\
\text { by trees }\left(\mathrm{m}^{2}\right)\end{array}$ & $39,161.30$ & $15,679.34$ & $11,750.25$ & $42,900.34$ & (Olaleye, 2013) \\
\hline Parameters & & & & Threshold \\
\hline $\mathrm{SPM}\left(\mu \mathrm{g} / \mathrm{m}^{3}\right)$ & $65.00 \pm 7.00^{\mathrm{a}}$ & $68.33 \pm 7.23^{\mathrm{ab}}$ & $78.33 \pm 7.23^{\mathrm{b}}$ & $58.33 \pm 4.73^{\mathrm{a}}$ & $150-250(\mathrm{EC}, 2016)$ \\
Noise $(\mathrm{dB})$ & $61.00 \pm 10.00^{\mathrm{a}}$ & $63.00 \pm 10.00^{\mathrm{a}}$ & $67.00 \pm 7.21^{\mathrm{a}}$ & $59.00 \pm 10.00^{\mathrm{a}}$ & $70 \mathrm{~dB}(\mathrm{WHO}, 2000)$ \\
\hline \multicolumn{5}{c}{ Values with the same superscripts along the row were not significantly $(p>0.05)$ different }
\end{tabular}

Table 6: Results of the SPM and noise at the non-greenspaces

\begin{tabular}{|c|c|c|c|c|c|}
\hline Parameters & Mile 12 & Jibowu & Ojuelegba & Iyana-ipaja & \\
\hline & & & & & Threshold \\
\hline $\operatorname{SPM}\left(\mu \mathrm{g} / \mathrm{m}^{3}\right)$ & $127.78 \pm 13.53^{\mathrm{ab}}$ & $109.08 \pm 8.84^{\mathrm{a}}$ & $121.55 \pm 13.09^{\mathrm{a}}$ & $146.48 \pm 13.53^{\mathrm{b}}$ & $150-250(\mathrm{EC}, 2016)$ \\
\hline Noise dB & $75.50 \pm 12.00^{\mathrm{a}}$ & $70.80 \pm 12.00^{\mathrm{a}}$ & $73.20 \pm 12.00^{\mathrm{a}}$ & $80.40 \pm 8.65^{\mathrm{a}}$ & $70 \mathrm{~dB}$ (WHO, 2000) \\
\hline
\end{tabular}

Average levels of SPM which serve as travelling medium for other related pollutants were high, though within the limit in both areas (Table 9). Levels of noise in both study areas were higher than the limit for human health: $70 \mathrm{~dB}$ (WHO, 2000).
Higher levels of pollution were observed around the non-greenspace than the greenspace areas (Figure 2). This might result from the anthropogenic activities, emissions from the increasing number of automobiles, time of the day when anthropogenic 
activities were high coupled with the sunrise which influences urban heat island effects, an evidence of global warming. The risks of urban heat island are possibly high in large metropolis (DEFRA, 2002), with non-greenspace areas. The intensity of the urban heat island is typically at peak several hours after sunset and in the absence of greenspaces which would have provided cooling effects. Thus, there would be higher levels of the criteria air pollutants $\left(\mathrm{CO}, \mathrm{SO}_{2}, \mathrm{NO}_{2}, \mathrm{O}_{3}\right.$ and $\left.\mathrm{SPM}\right)$ in the non-greenspaces. This in turn would increase levels of greenhouse gases and possible global warming effects. Therefore, this should create concern to general public that greenspaces mitigating measures which started in Lagos State before 2009 should be extended for its cooling effects.

Table 7: Average values of gaseous parameter in both study areas

\begin{tabular}{llll}
\hline Gaseous parameter & Greenspaces & Non-greenspaces & Threshold \\
\hline $\mathrm{CO}\left(\mu \mathrm{g} / \mathrm{m}^{3}\right)$ & $3.76 \pm 1.23$ & $4.70 \pm 1.59$ & $40(\mathrm{EC}, 2016)$ \\
$\mathrm{CO}_{2}\left(\mu \mathrm{g} / \mathrm{m}^{3}\right)$ & $8.39 \pm 1.50$ & $14.68 \pm 2.62$ & $10(\mathrm{EC}, 2016)$ \\
$\mathrm{NO}_{2}\left(\mu \mathrm{g} / \mathrm{m}^{3}\right)$ & $1.94 \pm 0.84$ & $2.57 \pm 1.11$ & $191-200(\mathrm{EC}, 2016)$ \\
$\mathrm{SO}_{2}\left(\mu \mathrm{g} / \mathrm{m}^{3}\right)$ & $0.32 \pm 0.54$ & $0.46 \pm 0.77$ & $198.75-350(\mathrm{EC}, 2016)$ \\
$\mathrm{VOC}\left(\mu \mathrm{g} / \mathrm{m}^{3}\right)$ & $2.08 \pm 0.65$ & $2.60 \pm 1.66$ & \\
\multicolumn{4}{l}{ Values with the same superscripts along the row were not significantly $(p>0.05)$ different }
\end{tabular}

Table 8: Average values of meteorological conditions in both study areas

\begin{tabular}{llll}
\hline $\begin{array}{l}\text { Meteorological } \\
\text { conditions }\end{array}$ & Greenspaces & $\begin{array}{l}\text { Non- } \\
\text { greenspaces }\end{array}$ & Threshold \\
\hline Temp. $\left({ }^{\circ} \mathrm{C}\right)$ & $41.25 \pm 6.92$ & $45.38 \pm 7.26$ & $<30(\mathrm{DoH}, 2008)$ \\
& $28.25 \pm 2.74$ & $21.73 \pm 2.09$ &
\end{tabular}

Values with the same superscripts along the row were not significantly $(p>0.05)$ different

Table 9: Average values of SPM and noise in both study areas

\begin{tabular}{llll}
\hline Parameters & Greenspaces & Non-greenspaces & Threshold \\
\hline $\mathrm{SPM}\left(\mu \mathrm{g} / \mathrm{m}^{3}\right)$ & $101.5 \pm 26.19$ & $189.34 \pm 48.99$ & $150-250(\mathrm{EC}, 2016)$ \\
Noise $\mathrm{dB}$ & $93.75 \pm 37.21$ & $112.50 \pm 44.65$ & $70 \mathrm{~dB}(\mathrm{WHO}, 2000)$ \\
\hline
\end{tabular}

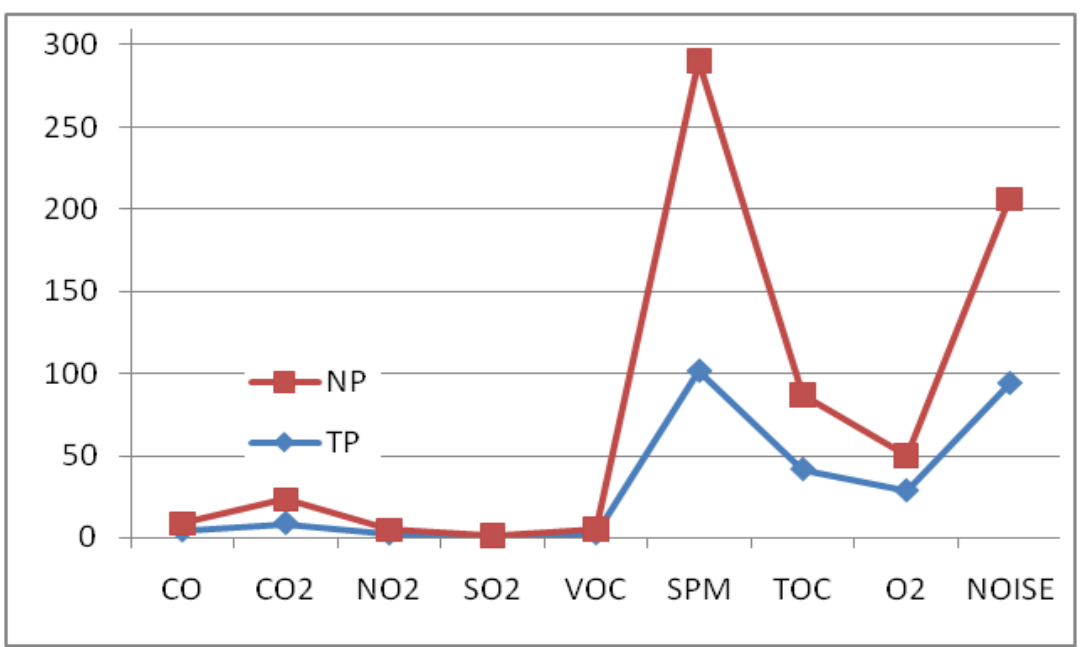

Fig 2: Graph of average values of the assessed parameters in both study areas $\mathrm{NP}=$ non-greenspaces, $\mathrm{TP}=$ greenspaces

Conclusions: Levels of $\mathrm{CO}_{2}$, noise and temperature in Mile 12 and Iyana-ipaja (non-greenspaces) exceeded the limits. Pollution levels in the non-greenspaces were not only related to vehicle volume, human population and commercial activities but also attributed to pollutants not being sequestered. Tree planting activities to increase greenspaces should be seen as responsibility of every individual to improve aesthetic values of and care for the environment. Creation of greenspaces will make environment safe and healthy through fresh and clean air, and abate possible effects of the global warming.

\section{REFERENCES}

DEFRA, (2002). The UK Climate Change Risk Assessment 2012 - Evidence Report. DEFRA, London. In: Forest Commission, England Document. 34pp. eng-trees-and-climatechange.pdf (Retrieved on 30/04/2016). 
DoH (Department of Health), (2008). Heatwave Plan for England. Protecting health and reducing harm from extreme heat and heatwaves. NHS/Department of Health, London. Pp. 1-43. http://docplayer.net/346760-Heatwave-plan-forengland-protecting-health-and-reducing-harmfrom-severe-heat-and-heatwaves.html (Retrieved on 17/06/2016).

EC, www.ec.europa.ue/environment/air/quality/stand ards.html (Retrieved on 26/03/2016).

Ezzati, M (2002). Selected Major Risk Factors and Global and Regional Burden of Disease. Lancet 360: $1347-1360$.

Haq, I; Hussain, T; Farooq, H; Ahmad, MR (2014). Evaluation of the Traffic Noise Pollution at some Busiest sites of Faisalabad City, Pakistan. Academic Res. Inter. 5: 23-26.

Karita, K; Yano, E; Jinsart, W; Boudoung, D; Tamura, K (2001). Respiratory Symptoms and Pulmonary Function among Traffic Police in Bangkok, Thailand. Arch. of Env. Health 56: 467-470.

Kumar, SR; Arumugam, T; Anandakumar, CR; Balakrishnan, S; Rajavel, DS (2013). Use of Plant Species in Controlling Environmental Pollution - A Review. Bul. of Env., Phar. and Life Sc. 2 (2): 52- 63.
Oduwaye, L (2006). Effects of Globalization on Lagos Cityscape. Res. Rev. Ns. 22 (2): 37-54.

Olaleye, DO (2013). Community Greening in Pre and Post Climate Change Knowledge Era in Third World Cities: Case study of Lagos, Nigeria. Civil and Env. Res. 3: 7-13.

Olayemi, S; Oluwafemi, OO (2013). Assessment of Tree Planting Efforts in Lagos Island Local Government Area of Lagos State, Nigeria. Env. and Nat. Res. Res. 3: 4-11.

Singh, N; Davar, SC (2004). Noise PollutionSources, Effects and Control. J. of Hum. Ecol. 16 (3): 181-187.

Thomasnet. (2011). http://www.thomasnet.com/articles/instrumentscontrols/How-Gas-Detectors-Work (Retrieved on $05 / 06 / 2016$ ).

West, JJ; Fiore, AM; Naik, V; Horowitz, LW; Schwarzkopf, MD; Mauzerall, DL (2007). Ozone Air Quality and Radiative Forcing Consequences of Change in Ozone Precursor Emissions. Geophys. Res. Let. 34(6): L06806: 10.1029/2006/GL029173.

WHO (World Health Organisation), (2000). Guidelines for Community Noise. Geneva: WHO. http://www.who.int/docstore/peh/noise/guideline s2.html (Retrieved on 26/03/2016). 